\title{
THE DECAY OF PERSONAL RIGHTS AND GUARANTEES ${ }^{1}$
}

Many civilizations which have entered the domain of history seem to present two evolutionary periods. The first period is that in which the individual seeks to safeguard himself against the excesses of arbitrary power, by extorting guarantees from the sovereign; the second is that in which these guarantees are gradually surrendered to the collective power of the mass.

The process by which English civilization has been, and is being developed, seems to establish the fact that the first of these periods has been concluded, and that the second has begun.

In the first of these periods the political instinct which the English people possess in so eminent a degree, busied itself with asserting and maintaining the rights of men. It is now a serious question, whether we are not more concerned in regulating their activities. Up to recent times this people were unalterably committed to the maintenance of certain rights which they considered fundamental, and without which they did not believe that liberty could permanently exist.

Among these rights, may be grouped the writ of habeas corpus, trial by jury, once in jeopardy, religious freedom, peaceable assemblage, a free press, free speech, and for every man due process of law.

Due process of law means that as to every matter which concerns a man's personal or property rights he must have his day in Court, and this Court must not be a thing merely named a Court, but must possess the essential attributes of a judicial tribunal.

That there is an ebb tide from these doctrines flowing swiftly at this time is apparent to the careful observer.

Several causes for this reaction may be differentiated. The energy of individualism in a virile race uncontrolled by tyranny, inevitably produces a populous civilization and therefore a complex one.

Each stage of this civilization produces a readjustment between the rights of the individual and the rights of society. Thus, in

1 Address delivered before the State Bar Association, of Maryland. 
every highly complex civilization, the individual right must, in innumerable cases, be subordinated to the collective right, and men thus gain as members of society what they lose as individuals.

In a society like ours, each unit is affected in a thousand ways by the activity of other units, and the more numerous the population, and the greater its activities, the more the individual must give up and the more the community acquires. There are other causes which are based less upon natural law, and more upon the infirmity of human nature. Among these is the growing tendency to regard the rights of property owners as superior to the rights of man, and to subordinate the individual to a social system which recognizes the attainment of wealth as the most desirable achievement of a prosperous society.

But, perhaps, the most potent because the most furtive solvent of personal rights is to be found in the immense mass of administrative law which in both State and Nation is absorbing the functions of government. Executive discretion is gradually in many directions emancipating itself from judicial control, and executive bodies are now frequently clothed with both judicial and legislative functions.

Whatever causes we may choose to assign, the decay of personal rights and guarantees is so universal, its manifestations are so numerous, it characterizes so many govermental activities, State and National, that it may rise to the dignity of and evolutionary process.

We find on every hand this reaction against individual rights controlling the opinions of men, the acts of legislatures, the interpretation of Courts and the declaration of political parties.

In certain directions, individualism is making a struggle for its life. The press, the hustings, the Law Courts resound with the din of battle.

Nowhere is the conflict of these mighty social forces more dramatically or more energetically waged than on the bench of the Supreme Court of the United States.

In this arena, under the eyes of the Nation, nne intellectual glacliators are struggling, some defending with precedent and logic the ancient gutarantees, others by arguments of impolicy and inconvenience seem to be breaking over the barriers of constitutional limitation. 
Wherever the strongholds of guaranteed rights are assailed strong dissentient voices arise from the bench, and as these strongholds fall one after another, as many have fallen, we find dissenting opinions expressing regret and forebodings.

The growth of administrative law is not peculiar to the Federal Government. Much attention has been focussed upon Federal Court and the Federal Legislature in connection with centralization of power, yet precisely the same influences are at work in the State Government. Commission after commission is being created, many of them with powerful and anomalous functions. For instance, the Virginia Constitution of 1902, has largely subjected that State to a bureaucratic government.

This Constitution created a State Corporation Commission, and conferred upon it legislative, administration and judicial powers, all to be exercised in the same proceedings and as to the same subject matter. A Board of Education was created, whose rules have the force of legislative enactment and whose acts are beyond the control of any other department of government.

Cities are demanding to be governed by commissions, and because of the popular zeal for quick results Congress and legislatures are creating special bureaus to deal with almost every phase of human activity.

The Courts have recognized the doctrine of executive independence where there is any discretion whatever, and this principle of law has been stretched until it now includes the power to pass upon rights which should demand a judicial investigation. The Federal executive departments exercise vast and generally uncontrolled power.

The Postoffice Department exercises a censorship of the press which, in its discretion, can be made more severe than that of Russia.

By issting what is known as a fraud order, any man's mail can be stopped, and any publication stispended, and the victim has no practical recourse.

The President of the United States has it in his power to deny a whole community postal facilities, as was done in the case of Indianola. Immigration officials have the uncontrolled power to banish any citizen of the United States who, having left this country, clesires to come back. The case of Mitchell ". Clark."

\footnotetext{
2 I 10 U. S., 633.
} 
presents a striking illustration of the omnipotence with which executive authority may be clothed. The Court in this case upheld the fourth section of the Act of March 3, 1863, I2 Stat., which is as follows:

"That any order of the President, or under his authority, made at any time during the existence of the present rebellion, shall be a defense in all Courts to any action or prosecution, civil or criminal, pending or to be commenced, for any search, seizure, arrest or imprisonment, made, done or committed, or acts omitted to be done under and by virtue of such order, or under color of any law of Congress, and such defense may be made by special plea or under the general issue."

The Court found a justification of this statute not in any power delegated by the Constitution, but in the general power of a government to indemnify its administrative officials.

In Hartrabnt's Appeal, ${ }^{3}$ it was held that neither the Governor nor any of his subordinates are amendable to court processes as to any matter pertaining to the duties of his office. This case arose from a clash between the State militia and certain strikers in which a number of persons were killed. The local Court committed the matter to a grand jury for investigation, and the grand jury subpoenaed the Governor and a number of militia officers to appear and give evidence, which they refused to do.

An interesting case, as marking the advance of administrative usurpation, is the case of $J_{u}$ Toy..

Ju Toy was a Chinaman, born in this country, and therefore not subject to the Chinese Exclusion Act.

Ju Toy paid a visit to China, and on his return to San Francisco, he was ordered to be deported by the immigration officials. Thereupon, he sued out a writ of haebas corpus from a Federal District Judge. In this Court it was upon evidence judicially established, that $\mathrm{Ju}$ Toy was a native American, anrl his release was ordered. From this judgment the Government appealed and the case was heard by the Supreme Court.

A majority of the Court held, Justice Holmes delivering the opinion, that even if Ju Toy was a native American, he could get no relief from the order of deportation, because the fincling of the immigration officials was conclusive, and not subject to judi-

$385 \mathrm{~Pa}$. St., 433.

4 I98 U. S., 253. 
cial review. Justices Brewer, Peckham, and Day dissenting. Iudge Brewer in the dissenting opinion, said:

"It will be borne in mind that the petitioner has been judicially determined to be a free-born American citizen, and the contention of the Government sustained by the judgment of this Court, is that a citizen guilty of no crime, for it is no crime for a citizen to come back to his native land, must by the action of a ministerial officer be punished by deportation and banishment, without a trial by jury, and without judicial examination. Such a decision is to my mind appalling. By all the authorities, the banishment of a citizen is punishment, and punishment of the severest kind."

A conspicuous foil to this case is the case of Miller v. Horton, ${ }^{5}$ in which the opinion was also delivered by Judge Holmes. In this case it appears that the Massachusetts State Commissioners on Contagious Diseases decided that the plaintiff's horse had the glanders, and ordered him shot. Here the Court held that it would go behind the finding of the Commissioners, and if it appeared that the horse was not in fact afflicted with glanders, the plaintiff had his action for damages against the Commissioners.

It is, perhaps, in the insular cases that we find the greatest divergence from the ancient landmarks. Whether controlled by the instinct which in societies seems to accompany a natural law of evolution, or whether controlled by more conscious motives, our Courts by arguments of impolicy or inconvenience, are in fundamental matters changing the force and meaning of written law.

This fact is well illustrated by the case of Hazvaii v. Mankichi, decided in 1903 .

Hawaii was annexed to the United States by virtue of the Newland's Resolution, which provided, among other things, that until changed by Congress, the municipal laws of Hawaii should govern where such laws were "not contrary to the Constitution of the United States." After the annexation, Mankichi was tried for manslaughter upon an information and was found guilty by the verdict of nine out of twelve jurors. Mankichi pled that such procedure was contrary to Articles 5 and 6 of the Amend-

5 I52 Mass., 540.

6 I90 U. S., 197. 
ments, in that he could not be put upon trial except by indictment, nor convicted except upon the unanimous verdict of twelve jurors. A majority of the Court held that Mankichi was not entitled to these Constitutional guarantees.

The majority opinions seem to be based upon two propositions: (I) That only so much of the Constitution as was specifically legislated by Congress into the Government of Hawaii prevailed there; (2) that though the Constitution of its own vigor applied to Hawaii upon annexation, nevertheless, only such provisions of the Constitution as were locally applicable could be considered the law of the land.

Justices Brown, Holmes, and Day seem to plant themselves upon the first proposition, and Justices McKenna and White upon the second.

Chief Justice Fuller, Justice Harland, Justice Brewer, and Justice Peckham dissented.

In a separate dissenting opinion, Judge Harlan says:

"Nevertheless, it is contended that the Constitutional provisions in question are not fundamental in their nature, that whether a person charged, for instance, with murder, shall be convicted and hung pursuant to a verdict rendered by a majority of the petit jury rather than all the jurors, is only 'a method of procedure.' My judgment refuses assent to this doctrine. I believe it to be most mischievous in every respect. The provisions as to grand and petit jurors are in the Constitution, and the mandatory character of that instrument ought not to be disregarded. What tribunal deriving its authority from the United States can rightfully hold them to be immaterial? Whether these provisions are fundamental in their nature or not, no Federal civil tribunal, existing under the Constitution and under a solemn obligation to maintain and defend it, can properly or safely ignore them. If the local law under which Mankichi was tried and convicted was contrary to any provision of the Constitution, that instrument should have been respected, whatever the nature of such provision."

This case overruled Webster $v$. Reid ${ }^{7}$ American Publishing Co. v. Fisher; ${ }^{7}$ Springfield $v$. Thomas; ${ }^{7}$ and Thompson v. Utah, ${ }^{\top}$ all of which decided that the right of trial by a constitutional jury applied to all territories of the United States, and that Con-

${ }^{7}$ II Howard, 437 ; I66 U. S., 464-468; I66 U. S., 707; 170 U. S., 243. 
gress could not deny this right nor permit it to be denied by territorial legislation.

The case of Thompson v. Utah was decided as late as April, 1898 , and this case held, that a statute of the State of Utah, providing for the trial of criminal cases other than capital, by a jury of eight, was invalid as applied on the trial of a crime committed before Utah was admitted into the Union; that it was not competent for the State of Utah, upon its admission into the Union, to do in respect of Thompson's crime what the United States coutd not have done, and that an Act of Congress providing for a trial by jury of less than tivelve, would have been in conflict with the Constitution.

The Thompson case and the Mankichi case measure the distance which the Supreme Court has in five years traveled towards the denaturizing of the guarantees of the Constitution.

In the case of Trono $\%$ Unitcd States, ${ }^{8}$ the facts were these: Trono was proceeded against without indictment or jury in the Court of the First Instance of the province of Bulacan, Philippine Islands. for murder in the first degree. He was acquitted of the crime of murder of any degree, but was convicted of assault, sentenced to six months' imprisonment and to pay a fine to the family of the dead man.

Trono appealed to the Supreme Court of the Philippine Islands, which reversed the lower court and convicted Trono of murder in the second degree, and sentenced him to fourteen years, eight months and one day imprisonment, and an indemnity to the heirs of the deceased. The majority of the Súpreme Court of the United States held that Trono was neither entitled to the benefit of the jeopardy clause of the Constitution, nor to a trial by jury, and affirmed the Supreme Court of the Philippine Islands. Chief Justice Fuller, McKenna, White, and Harlan disscinted.

In the case of Dc Lima z. Bidrcell $^{\circ}$ the majority of the Court held, that with the ratification of the treaty between the United States and Spain, April II, I899. the Island of Porto Rico ceased to be a foreign country within the meaning of the tariff law.

This case was followed on the same day by the decision in

\footnotetext{
8199 U. S. 52 r.

${ }^{9} \dot{8}_{2}$ U. S.. p. I.
} 
Dooley $v$. United States, ${ }^{10}$ to the effect that "as the right to exact duties upon importation from Porto Rico ceased with the ratification of the treaty of peace, the correlative right to exact duties upon imports from New York to Portu Rico also ceased at the same time."

On the same day the Supreme Court decided the case of Downes v. Bidwell. ${ }^{11}$

In this case the majority of the Court, Fuller, Harlan, Brewer, and Peckham, dissenting, held that Porto Rico, which under the De Lima decision, had ceased to be foreign territory in respect to the tariff laws, became again on the I2th of April, I900, foreign territory as to that provision of the Constitution, which declares that "all duties, imports and excises, shall be uniform throughout the United States," being made such foreign territory as to taxation by an Act of Congress, of the latter date, imposing tariff duties on Porto Rico products, imported into the United States. The Court decided on the general lines of the Mankichi case, the majority holding either that the Constitution did not govern unless so willed by Congress, or if it did govern it, was not in force as to such provisions not deemed fundamental, or were not, in the opinion of the Court, applicable to the conditions existing in the Island.

In opposition to this reasoning the dissenters quote Judge Cooley, as follows: "The Constitution itself never yields to treaty or enactment; it neither changes with time nor does it in theory bow to the force of circumstances. It may be amended according to its own permission, but while it stands, it is a law for rulers and people. Equally in war and in peace, it covers with the shield of its protection all classes of men, at all times and under all circumstances. Its principles cannot, therefore, be set aside, in order to meet the supposed necessities of a great crisis. No doctrine involving more pernicious consequences was ever invented by the wit of man, than that any of its provisions can be suspended during any of the great exigencies of government."

Judge Harlan, in a separate dissenting opinion, says:

"I take leave to say that if the principles thus announced should ever receive the sanction of a majority of this Court, a radical and mischievous change in our system of government will be the

10 I82 U. S., 222.

11 I 82 U. S., 244. 
result. We will, in that event, pass from an era of constitutional liberty, guarded and protected by a written constitution, into an era of absolutism."

And further: "Again, it is said that Congress has assumed in its past history, that the Constitution goes into territories acquired by purchase or conquest only when and as it shall so direct. This is a view of the Constitution which may well cause surprise as well as alarm. Congress, as I have observed, has no existence except by virtue of the Constitution. It has no power which that instrument has not granted, expressly or by necessary implication. I confess that I cannot grasp the thought that Congress, which lives and moves and has its being in the Constitution, and is consequently the mere creature of that instrument, can at its pleasure, legislate or exclude its creator from territories which were acquired only by the authority of the Constitution."

Dorr v. United States ${ }^{12}$ decided that Congress could deny to the citizens of the Philippine Islands the right of trial by jury, and follows the reasoning of the Mankichi case.

Out of the entangled, perplexed and often inconsistent argument of the majority justices in these insular cases, two wholly new principles of constitutional law seem to emerge.

One is that the Constitution does not inherently and of its own vigor apply to territories of the United States, and does not become operative in such territories except and until it is made operative by an Act of Congress, and in such cases only so much of the Constitution as the Act itself directs shall govern. The other is that some provisions of the Constitution are fundamental and mandatory, and others are matters of procedure, which need not be regarded if their enforcement would seem impolitic or inconvenient.

If the Constitution can only be carried into territories of the United States by an Act of Congress, then the Constitution has no other sanction than the Act itself, and it is carried not as the Constitution, but as the will of Congress.

Therefore, an Act of Congress can repeal the rights which the Act created, and the people of such territories can only have a legislative recognition for such rights as they are allowed to possess, and these rights may be taken away by the same power that gave them.

${ }^{12}$ I95 U. S., 138. 
If some provisions of the Constitution are fundamental and binding and others are not, it follows that the Court must ascertain what provisions are binding and what are not. The validity and obligation of any part of the Constitution at any given time must depend upon the opinion of a majority of the nine judges composing the Supreme Court of the United States.

In five years we have seen Constitutional guarantees for a hundred years deemed impregnable, crumble in the hands of the Court. We are told that the writ of habeas corpus, the right to trial by jury, the exemption from prosecution for a felony save by the presentment or indictment of a grand jury, the mandate for uniform tariffs and excises are not of the essence of rights; but in their application to be controlled by policy and convenience.

It cannot be denied that these insular decisions have opened the door wide to the doctrine of amendment by interpretation, and that since these decisions it cannot be said that the Constitution is inviolate in its written provisions.

If the Court does not recede from these principles of construction, the supreme law of the land will not be the Constitution of the United States, but the will of nine elder statesmen sitting in judgment over the Federal and State Legislatures and giving judgment not in accordance with written law, but upon some theory of statecraft. In other words, the Court will become the legislature of the last resort.

The -decay of our guaranteed personal rights means the death of individualism and the tyranny of infinitely complex laws, consisting of administrative rules, legislative requirements and judicial decisions, subject to constant adjustment to meet supposed political or social necessities.

This condition will bring about a profound change in our system of government, but the change, I think, will not be for the better.

The unhappy condition of the State of Colorado is an example of the anarchy which may ensue where the constitutional guarantees are not respected by the executive or enforced by the Courts.

In that State not long ago, the writ of habeas corpus was suspended, trial by jury was denied, men were imprisoned without accusation and deported without authority. The Supreme Bench constituted itself a returning board, and established by a so- 
called high prerogative writ its power over elections. A military and judicial autocracy banished every semblance of constitutional government.

This lesson should be carefully studied. Human freedom is not a gift to man; it is an achievement by man, and, as it was gained by vigilance and struggle, so it may be lost by indifference and supineness. Richard Evelyn Byrd. 